\title{
Chronobiology: implications for marine resource exploitation and management
}

\author{
ERNEST NAYLOR \\ School of Ocean Sciences, University of Wales-Bangor, Marine Science Laboratories, Menai Bridge, \\ Anglesey LL59 5AB, UK. E-mail: e.naylor@bangor.ac.uk
}

\begin{abstract}
SUMMARY: Chronobiology began as a curiosity-driven science and now impacts significantly on the science of medicine through medical rhythm research and chronotherapeutics. However, whilst it has long been evident that rational exploitation and management of living organisms and their environments require detailed biological understanding, incorporation of the time-base of living systems into such activities has been slow. Evidence suggests that marine management and conservation strategies, whether directed towards the environment or fisheries, are only slowly taking account of the time-scales of endogenously controlled rhythmic animal behaviour as a basis from which to achieve their objectives. Similarly, in commercial aquaculture practices, there is a need for greater evaluation of the role of photoperiod manipulation and optimization of feeding regimes against the background of the endogenous rhythmicity of the organisms concerned. Correct synchronization of an organism's endogenous biological oscillators, of tidal and/or daily to annual periodicities, is fundamental to its optimal physiological performance and survival.
\end{abstract}

Keywords: chronobiology, marine exploitation, management, rhythms, rhythmic behaviour.

RESUMEN: CRONOBIOLOGÍA: IMPLICACIONES PARA LA EXPLOTACIÓN Y GESTIÓN DE RECURSOS MARINOS. - La cronobiología se inició como una ciencia dirigida por la curiosidad y hoy día impacta significativamente en la ciencia de la medicina a través de investigación médica sobre ritmos y cronoterapéutica. No obstante, mientras que ha sido evidente por mucho tiempo que la explotación y gestión racional de los organismos vivos y de su ambiente requiere una detallada comprensión biológica, la incorporación de la base temporal de los sistemas vivos en tales actividades ha sido lenta. La evidencia sugiere que las estrategias de gestión y conservación marinas, ya sea dirigidas hacia el ambiente o a las pesquerías, están tomando en cuenta únicamente de una manera lenta las escalas temporales del comportamiento animal rítmico controlado endógenamente como una de las bases con las que conseguir sus objetivos. De manera similar, en prácticas de acuicultura comercial, existe una gran necesidad para una mayor evaluación del papel de la manipulación del fotoperíodo y de la optimización de los regímenes de alimentación respecto a la ritmicidad endógena de los organismos. Una correcta sincronización de los osciladores biológicos endógenos de un organismo, con periodicidades mareal y/o diaria a anual, es fundamental para el funcionamiento fisiológico óptimo así como para la supervivencia.

Palabras clave: cronobiología, explotación marina, gestión, ritmos, comportamiento rítmico.

\section{INTRODUCTION}

Chronobiology, the study of biological rhythmicity in living organisms, began as a curiosity-driven science. Daily patterns of behaviour in animals and plants, in some cases persisting in constant conditions, have been recognized for two centuries or more. In the early eighteenth century, for example, the French astronomer de Mairan observed that the daily leaf movements of Mimosa continued in plants placed in continuous darkness in a cellar (Daan, 1982). Yet a reluctance to accept control of such behaviour by internal biological clocks persisted until the second half of the twentieth century. Semon 
(1905) defended the idea that animals and plants that expressed daily rhythms of behaviour in constant conditions did so by learning during their lifetime to respond rhythmically to cyclical changes in their environment. Subsequently, as late as the latter half of the twentieth century, Brown and others (see Brown, 1960, 1972) continued to reject the notion of internal biological clocks, insisting that biological rhythms in constant conditions were driven by residual variables that pervaded the environment and which were not controlled in so-called constant conditions in the laboratory. Such interpretations persisted despite crucial observations such as those of Kleinhoonte (1928, see Daan, 1982) concerning the behaviour of another plant, Canavalia. The periodicities of the "daily" rhythms of leaf movement of this plant in constant light were shown to deviate from $24 \mathrm{~h}$ at circadian, that is, approximately daily periods quite different from any known residual geophysical variable that might drive such rhythms in otherwise "constant conditions" in the laboratory. This prescient finding and numerous later examples in plants and animals now confirm that many biological rhythms are endogenous, free-running at periods approximating to environmental cycles when deprived of exposure to such cycles in the laboratory.

Today the concept of the circadian body clock is well accepted, based on a wealth of curiositydriven science, and it now forms the basis of several aspects of human medicine. Apart from its implications for the understanding of sleep and wakefulness, circadian patterns are apparent in various physiological processes and in human susceptibility to medicinal drugs. Scientific journals and conferences commonly combine papers on chronobiology with others, for example, on medical rhythm research and chronotherapeutics. When jet-lagged chronobiologists meet at international conferences, discussion of the merits and demerits of ingesting melatonin, a mediator of the circadian clock system, becomes of more than academic significance. At such conferences one also meets the occasional chronobiologist interested not only in circadian rhythms but also in circatidal rhythms. Such biologists are rare because the study of biological rhythms in marine animals and plants subjected to ocean tides is a Cinderella-subject compared with the study of biorhythms in terrestrial animals and man (Palmer, 1995a). The process of adaptation to solar variables in the environment has been more readily accepted than adaptation to lunar variables. Early reluctance to accept the possibility of direct control of animal behaviour by moonlight (Korringa, 1957) was understandable. However, experimental approaches in recent decades have demonstrated lunar influences on animal behaviour both indirectly through the influence of ocean tides and directly through moonlight itself (Naylor, 2001).

There are differences in the characteristics of circadian and circatidal rhythms as expressed by animals in constant conditions in the laboratory. Circadian rhythms, which free-run at approximately $24 \mathrm{~h}$ periodicity, often do so for many days or weeks in the laboratory, with little change in the characteristics of the peaks of the rhythm. In contrast, circatidal rhythms of behaviour in marine animals usually free-run for only a few days in the laboratory and, in many cases, "activity" peaks relatively quickly become diffuse. The differences may be due to the predictability of $24 \mathrm{~h}$ light/dark changes in the environment compared with the relative variability of tidal time-cues. Tide times and amplitudes vary considerably over short geographical distances and in response to local weather conditions. Matching this contrast between circadian and circatidal rhythms are the relative states of knowledge concerning the nature of the biological clockwork controlling such rhythms. Hormonal and neural physiological mechanisms driven by clock-genes are well understood to control circadian rhythms (Helfrich-Foster, 1995 ). In contrast, whilst hormonal and neural mechanisms have been shown to be involved in some circatidal rhythmic processes (Naylor, 1988; Aréchiga and Rodríguez-Sosa, 1997), little is known about the genetic basis of such rhythms (Palmer, 1995a). Indeed there is even debate as to whether or not true circatidal rhythmicity exists at the physiological level in coastal animals. Conflicting hypotheses that postulate control by truly circatidal clockwork (Naylor, 1996, 1997) or by paired circalunidian clocks coupled in antiphase (Palmer, 1995b, 1997) remain to be resolved. Nevertheless there is considerable evidence that coastal marine animals do exhibit endogenously controlled rhythms of physiology and behaviour that match the rhythms of ocean tides (Palmer, 1995a; Naylor, 2002) and even lunar phase (Naylor, 2001). These aspects of chronobiology have considerable implication for a range of applied marine sciences from fisheries and aquaculture to conservation and management of coastal environments. 


\section{BIORHYTHMS AND COASTAL ZONE MANAGEMENT}

In a major evaluation of the world's seas at the turn of the millennium (Sheppard, 2000) environmental quality and resource exploitation issues were discussed in the context of coastal resource management achieved or politically aspired to for many of the world's regional seas. Not surprisingly a common theme that emerged was that increased human population density inevitably induces pressure on environmental quality and sustainable exploitation of natural coastal resources. Response to such pressure clearly requires integrated management schemes that take account of coastal animal populations that are at risk. In this context it is critical to understand life-history changes and the time-base of behaviour of coastal animal populations over timescales from tidal, through daily, neaps/springs and seasonal, to annual and inter-annual periodicities.

It goes without saying that for resident coastal animals which reproduce by releasing planktonic larvae in inshore waters, environmental management practices should clearly take account of the life-style changes of the animals during development. However, very little attention has been paid to developmental differences in the biology and behaviour of coastal animals that undergo direct development. When juveniles and adults of the same species occupy what appears to be the same habitat the same management practices might reasonably be applied, irrespective of the stage of development of the animals concerned. Such sand-beach species that might be impacted by human activities are the talitrid amphipod crustaceans, so-called sand hoppers that are among the most abundant supralittoral and intertidal detritivores on temperate beaches worldwide. Characteristically, particularly from observations of adults, they burrow in sand in the strandline zone during their inactive phase, usually by day. Here they are particularly vulnerable to mechanical raking of tourist beaches when they could be exposed to visually feeding birds. During their normal active phase at some stage of the diel cycle the hoppers emerge naturally from sand, usually during darkness, to forage upshore or downshore dependent upon the local tidal conditions. On tidal shores they forage downshore but on non-tidal shores such as in the Mediterranean they forage upshore at night, presumably avoiding visual predators as they do so. However, such generalizations obscure the fact that several authors have observed differences in the phasing of surface foraging activity between adult and juvenile members of the same species of sand hopper (see Naylor and Kennedy, 2003). Indeed, in a study of the sand hopper Orchestoidea tuberculata on a tourist beach at Mehuin, Chile $\left(39^{\circ} 25^{\prime} \mathrm{S}\right.$, $\left.73^{\circ} 13^{\prime} \mathrm{W}\right)$, Kennedy et al. (2000) found that during daytime low tides adults typically burrowed near the high water mark whilst juveniles most commonly burrowed amongst algal fragments on damp sand on the lower shore. A grid of pitfall traps was set out to capture adults and juveniles during their foraging times, establishing that adults did so mainly at night whilst juveniles did so mainly around dusk and dawn. The study found that the two life history stages kept actively apart, adults out-competing juveniles by cannibalism when the two stages were kept together in the laboratory.

Selection pressure for separation of the two stages is evidently considerable since patterns of nocturnal locomotor activity in adults and crepuscular activity by juveniles were found to be expressed as typical circadian rhythms by hoppers kept in constant conditions in the laboratory. Moreover it was found that the inherited homing directions of juveniles and adults were complementary to each other during the day and at night. Orientation behaviour was tested by placing hoppers at the centre of a circular arena one half of which was bounded by a black wall and the other half by a white wall. During

\section{Orchestoidea tuberculata}

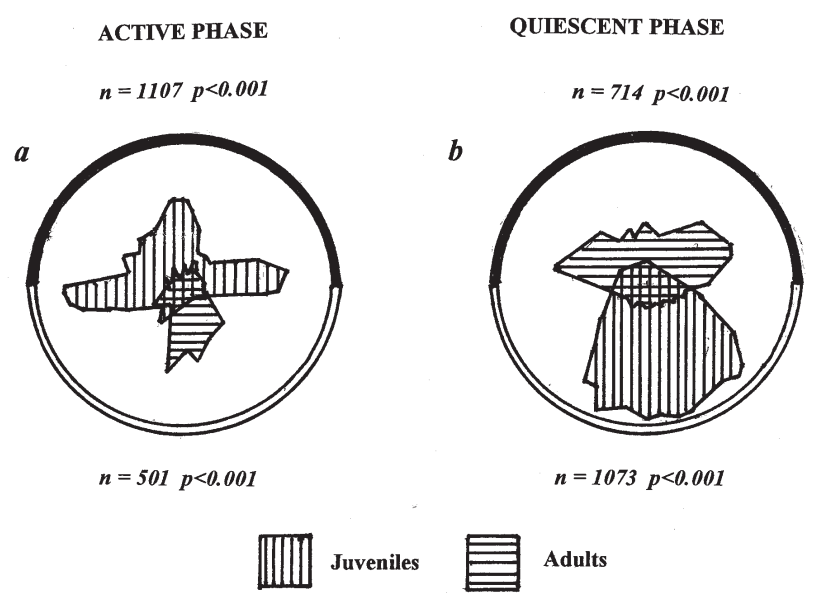

FIG. 1. - Escape directions of the littoral amphipod Orchestoidea tuberculata released at the centre of a uniformly lit experimental arena bounded by 180 degree black and white walls simulating upshore and downshore directions. Escape directions are pooled data, respectively, for: a) 1107 juveniles and 501 adults collected during the active phases of their circadian locomotor activity cycles, at dawn/dusk and night-time respectively; b) 714 adults and 1073 juveniles collected during the inactive phases of their circadian locomotor activity cycles, during daytime and midday-midnight, respectively. (After Naylor and Kennedy, 2003). 
their periods of high activity when normally foraging on the shore, the homing direction of adults was towards the white boundary and that of juveniles towards the black boundary (Fig. 1a). If the white boundary is taken to mimic the direction of brighter illumination in the direction of the sea and the dark boundary assumed to mimic the direction of darker sand dunes, then the responses are consistent with observed behaviour of adults foraging downshore and juvenile foraging upshore during their active periods on the beach. In contrast, when hoppers were tested in the arena during their inactive periods, adults orientated towards the black boundary and juveniles towards the white boundary (Fig. 1b), consistent with the respective preferences of adults to burrow high on the shore and juveniles on the lower shore. Clearly any attempt to understand the dynamics of a population of coastal animals such as this, as a basis for the establishment of beach management practices, should take account of life-history changes and marked differences in behaviour of adults and juveniles at particular times of day.

On longer timescales it goes without saying that annual breeding cycles must be taken into account when assessing the status of animal populations but, between biological rhythms of tidal or daily periodicity on the one hand and annual periodicity on the other, account should also be taken of biological events of lunar (29.5 d) and semilunar periodicity, related directly to the phases of the moon or indirectly to the moon in response to the neaps/springs cycle of tides. Several species of tropical and subtropical fiddler crabs of the genus Uca exhibit such rhythmicity. During the breeding season, females move in large numbers from estuaries, marshes and mangroves to release their larvae at the sea's edge during spring high tides, that is around the times of full or new moon (Naylor, 1988). Such phenomena can be observed casually and are unlikely to be missed in assessing coastal communities when formulating coastal management procedures. However, critical sampling procedures would have to be in place to detect changes in spawning times that might take place as the times of highest spring tides switch from the time of full moon to that of new moon, as they do every fourteen months or so on the so-called syzygy inequality cycle of tides (Skov et al., in press). Also, the fortnightly variation in some coastal animal populations that occurs between neaps and springs would remain undetected by inadequate sampling regimes. For example, Hastings and Naylor (1980) showed, for the sand-beach iso- pod Eurydice pulchra, numbers of adults and juveniles in the surf plankton varied differently over a lunar month. Juveniles emerged from sand to feed in the rising tide waters during each tide, but adult males and females emerged to feed only around the times of high spring tides. Without such information, tow net catches taken only at the times of neap tides would collect mainly juvenile isopods and grossly underestimate the size of the adult population. Management practices that might ignore one phase of an animal's development in this manner, may clearly have an adverse effect upon survivorship of the species as a whole. In the context of exploitation and management of beach systems, it is clearly necessary not to rely on spot sampling to obtain biological data, and over-generalizations concerning distribution and behaviour are to be guarded against. It is becoming increasingly apparent (Pitman and McAlpine, 2003) that studies of marine animals have rarely been undertaken at scales appropriate to the way in which animals exploit the multiplicity of scale and habitat types over their whole life cycles. Without scale-specific information on animal movements, marine conservation and management strategies are unlikely to achieve their objectives (Naylor and Kennedy, 2003; Pitman and McAlpine, 2003).

\section{CHRONOBIOLOGICAL ASPECTS OF FISHERIES}

A key requirement for stock assessment by fisheries biologists is an understanding of the predictability of spawning times. Such information is crucial when seeking to provide advice for the sustainable management of commercially important fish species. Early studies of this problem sought to determine whether fish spawning seasons exhibited regularity that was in some way related to cyclical events in the environment. Cushing (1969) addressed the question using long time-series of spawning dates from fisheries records for southern North Sea plaice (Pleuronectes platessa), Norwegian herring (Clupea harengus), Canadian Fraser River sockeye salmon (Onchorhynchus nerka) and Arctic cod (Gadus morhua). Each of these fish was shown to have a characteristic spawning time of a few days only each year, and for three of the species their spawning times were constant from year to year. Arctic cod did show a slight delay in spawning dates over time, but only by about eight days in sev- 
enty years. Spawning events typically coincide approximately with springtime production of phytoplankton, upon which the newly spawned fish larvae feed, but the spring phytoplankton bloom shows greater variability than the timing of fish spawning. If the two events coincide it heralds a successful year-class of fish; if they do not then the stock may survive at only low levels during a poor year, hopefully to recover later. This "match/mismatch" hypothesis, originally put forward to help explain recruitment variability in fish stocks, has been challenged but was nevertheless updated by Cushing (1990) who invoked it also to explain variability in commercial stocks of some lobsters and crabs. Subsequently Cushing (1996) developed the hypothesis further, incorporating a new idea that variation in recruitment of fish stocks is reduced when spawning takes place over a protracted period.

The implication of the "match/mismatch" hypothesis is that spawning is not triggered by a particular phase of the annual cycle of plankton production. Indeed, Cushing (1969) concluded that since fish can only link their spawning times to plankton production cycles in an indirect manner, it is to their advantage if they spawn at a relatively fixed season. In this way, he argued, a fish population has the best chance of profiting from the variability in the timing of the production cycle. From the point of view of the chronobiologist, repeatability of annual spawning dates is of interest in suggesting that the fish (and crustaceans) concerned possess endogenous circa-annual biological clocks that control spawning. The physiological clock mechanism controlling spawning can be envisaged as having evolved against the background annual periodicity of environmental events in the ocean. Seasonal changes in day-length and temperature are less well defined in the sea than on land, and may therefore be minor synchronizers of fishes' annual biological clocks. However, it is not unreasonable to postulate that circa-annual spawning rhythms of higher latitude species of fish have evolved against seasonal changes in day length and temperature, together with the averaged seasonal timing of plankton production over evolutionary time, even though the timing of production cycles is more variable than spawning. Future studies may yet find evidence of circa-annual endogeneity in plankton production cycles. However, at the present time, annual spring and autumn outbursts of plankton production in temperate seas can perhaps most conveniently be regarded as exogenous events, dependent most heavily upon responses to sea temperature and weather conditions, particularly wind strength and direction that influence stirring of the sea and upwelling of nutrients to the surface.

In further support of this interpretation of the control of fish annual spawning rhythms is the comparison made (Cushing, 1969) between the precise spawning times of plaice, cod, herring and sockeye salmon on the one hand and the irregular spawning times of Californian sardine and Pacific tuna on the other. The last two species breed at low latitudes where seasonality is much less pronounced than in the higher latitude breeding grounds of the first four species of fish. In chronobiology terms these observations suggest that at low latitudes there has been little evolutionary advantage in the acquisition of endogenously controlled circa-annual breeding times such as have been selected for in higher latitude species subjected to marked environmental seasonality.

Experimental demonstration of endogenous annual rhythms in fish is not easily forthcoming, given the requirement to maintain test animals in controlled laboratory conditions for very long periods of time. However, some evidence of the phenomenon in fish has become available from aquaculture studies (Dustan and Bromage, 1986) as it has also for some polychaete worms (Olive, 1984; Bentley et al., 2001). Intuitively, there is a high probability of the widespread occurrence of endogenous circa-annual rhythmicity in animals living where annual environmental cycles prevail. This is a reasonable extrapolation from the occurrence of endogenous rhythms of circatidal, circadian, circasemilunar and circa-lunar periodicities that have been demonstrated experimentally in many coastal organisms (Naylor, 1982, 1985, 2002; Palmer, 1995a; Gibson, 2003).

Interestingly, there is a sharp contrast between the annual spawning patterns of the fish and those of polychaete worms that have been studied so far. Whereas the four species of annual spawning fish reported by Cushing (1969) appear to spawn at a set time of year, apparently fairly precisely timed by their internal physiology, the annual spawning times of polychaetes may vary somewhat from year to year, though in a predictable manner. The latter are envisaged as being under the control of "gated" rhythms of circa-annual periodicity (Olive, 1984; Bentley et al., 2001). Individuals that reach the stage of reproductive readiness at the appropriate time of year will reproduce at some time when the "gate" is 


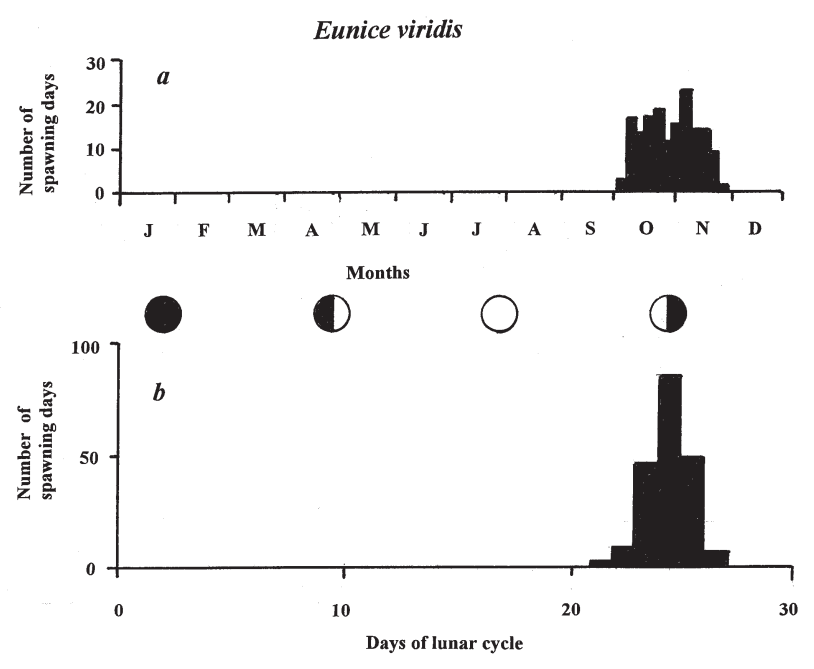

FIG. 2. - Spawning dates of the Pacific Palolo worm Eunice viridis around the Samoan Islands. The plots are of pooled data derived from 78 years of discontinuous recorded spawnings from 18431999: upper- dates grouped in 5-day intervals over the calendar year; lower- dates grouped in 1-day intervals over the lunar cycle. (Data provided by the Samoan Fisheries Division, after Naylor, 2001).

open, the precise timing often being correlated with a particular lunar or tidal phase. In contrast to the fish species described earlier, precisely-timed spawning occurs not only in temperate species, but in tropical species too. A classical example of the phenomenon of gated rhythms is seen in the Pacific Palolo worm (Eunice viridis) which is fished for food around the Samoan Islands (Caspers, 1984; Naylor, 1985, 2001). At the time of spawning these reef-living polychaetes release into coastal waters vast numbers of epitokes, posterior segments of their bodies that are laden with eggs or sperm. The large biomass of swarming epitokes forms the basis of a local food fishery for a few days each year. The days of the fishery are highly predictable, based on the Palolo "calendar" (Fig. 2), derived from 78 years records of Palolo spawning documented irregularly over the years 1843 to 1999 and kindly made available by the Fisheries Division, Samoa. Spawning takes place mainly during three days around the times of the third quarter of the moon that occur over a six to seven week period in October and November. In some years there is only one third quarter during the period of potential reproduction whilst in other years there may be two, in which case worms that did not spawn on the first of the two lunar quarters may do so on the one that occurs 29 days later. In the case of the Palolo, an endogenous circa-annual rhythm of reproduction determines the approximate six-seven week interval of spawning and some characteristic of the lunar cycle deter- mines the precise timing. It remains to discover whether the precise timing of Pacific Palolo spawning is phased directly by moonlight, as occurs in another marine polychaete (Hauenschild, 1960) or indirectly by neaps/springs variations in tides, as occurs in some other marine organisms (Naylor, 2001). Given this precision of spawning times in some invertebrates it also remains to establish how it is that high latitude fish, such as those reported by Cushing (1969), are so imprecisely phased to the primary production cycle, resulting in the population recruitment fluctuations that contribute to the problems of fisheries management (Browman and Stergiou 2004).

Of further concern in fish stock assessment is a need to understand patterns of behaviour of fish and other commercial species over different timescales. Annual migrations between breeding and feeding grounds have long been recognized, as have the processes of retention and recruitment of commercial species in tide-swept estuaries. Early studies by Wood and Hargis (1971) demonstrated how populations of the oyster Crassostraea virginica in the James River estuary (Virginia, USA) are self-replenished, despite intensive commercial harvesting and the risk of seawards transport of the free-swimming larvae. Larvae were shown to predominate near the estuary bed where the risk of seawards flow would be reduced during ebb tides, but to swim actively upwards into the water column during inwardlyflowing flood tides. This behaviour was shown to retain the larvae near the adult oyster beds within the estuary. More recent observations have also been made on a number of other commercial molluscs, crustaceans and fish in estuaries, which achieve retention or recruitment of dispersed larvae, juveniles or adults back into estuaries by the process of selective tidal-stream transport (Jager, 1999; Forward and Tankersley, 2001; Gibson 2003). Similar observations have also been made on species in inshore coastal seas where tidal streams are strong, with clear evidence emerging in several species of endogenous clock control of tidal rhythms of dispersal and recruitment behaviour (Zeng and Naylor, 1996a,b; Forward and Tankersley, 2001; Gibson, 2003). In offshore waters, too, there is evidence that vertical migration rhythms, in that case of daily periodicity, assist the dispersal of larvae by utilization of different ocean currents at different depths. For example, phyllosoma larvae of the rock lobster (Panulirus cygnus), commercially fished in western Australian waters, are commonly found up to 200 
$\mathrm{km}$ or more offshore, yet many clearly return to restock the adult population along the coastline. Offshore dispersal appears to result from upward swimming at night into surface waters that are influenced by westwards-blowing winds. When the winds reverse and blow eastwards by day, the larvae sink 30-60 $\mathrm{m}$ below the surface, thus avoiding the windaffected surface water layer (Rimmer and Phillips, 1979). The larvae eventually return to the western Australian coastline by exploiting deep inshore flowing ocean currents. In many of the examples cited above, advances in chronobiology theory have been invoked to explain the behaviour of recruiting larvae or adults, as they have also to help explain the long-standing problem concerning the control of vertical migration rhythms of oceanic plankton and fish in general (Nielson and Parry 1990). Indeed, there is now recognition of underlying multi-oscillatory physiological processes in the organisms concerned which are therefore not solely driven by external rhythmic stimuli as originally thought (Longhurst, 1976).

Furthermore, behavioural differences over tidal and diel time-scales are critical in terms of catchability of bottom-living species and, consequently, on commercial stock management. For example, it has for some time been recognized that variable catches of epibenthic crustaceans in commercial trawls are in some cases attributable to rhythmic patterns of behaviour, by which animals intermittently swim upwards off the bottom or hide in burrows (AlAdhub and Naylor, 1977). Notably, variations throughout the day in commercial catches of Norway lobsters (Nephrops norvegicus) in European waters (Chapman and Rice, 1971) were confirmed and shown to be partly related to endogenous circadian rhythms of burrowing behaviour (Naylor and Atkinson, 1976; Atkinson and Naylor, 1976). When caught from continental shelf depths of 10-184 m off the west coast of Britain Nephrops, maintained in artificial burrows in constant conditions in the laboratory, exhibited an endogenous nocturnal rhythm of locomotor activity. Curiously, peaks of activity were expressed at times when the prawns normally remained mainly within their burrows, as if in nature they were concerned with burrow excavation and maintenance at those times. They ventured out only occasionally at night, and the occurrence of this endogenous rhythm appears to explain why so few of the prawns are caught in trawls by fishermen at night. The nature of the spontaneous burrow-orientated activity of Nephrops at night seems to permit them to avoid capture by sheltering in their burrows when trawls are hauled over the seabed. The largest catches of Nephrops are usually taken by day, particularly after dawn and before sunset. Daytime catches are not dependent upon an endogenous rhythm of emergence; evidently at these times the prawns forage intermittently outside their burrows for food according to their hunger-state. In many localities lower catches around noon are probably the result of increased satiety at that time, which reduces the number and distances of feeding excursions away from the vicinity of the burrows (Oakley, 1979; Moller and Naylor, 1980). However, in shallow waters reduced catches around midday may occur because light suppresses emergence, particularly in view of the poor light-adapting responses of the retinal-shielding pigments of the prawn (Aréchiga and Atkinson, 1975; Loew, 1976).

More recent studies of Nephrops norvegicus have been carried out in the western Mediterranean, where commercial trawling takes place at depths greater than $50 \mathrm{~m}$ on the continental shelf and where largest catches are taken at dusk and dawn. Aguzzi et al. (2003, 2004) compared catchability and behaviour of prawns at $100 \mathrm{~m}$ depth on the continental shelf and at the greater depth of $400 \mathrm{~m}$ on the continental slope. Trawling at $100 \mathrm{~m}$ yielded greatest catches around dusk and dawn, though with some prawns captured at night, and at $400 \mathrm{~m}$ greatest catches were taken by day. Moreover, in laboratory experiments, prawns collected at $400 \mathrm{~m}$ depth exhibited endogenous circadian rhythms of locomotor activity with peaks occurring during subjective night. As in Atlantic coast populations, daytime catches of prawns at $400 \mathrm{~m}$ depth are not dependent upon the circadian rhythm of emergence from their burrows. which again did not coincide with the times of greatest catches of prawns in trawls.

In that study, Aguzzi et al. (2003) emphasize that the differences in catchability at the two depths studied have important implications for management of the fishery as a whole. In the NW Mediterranean night trawling is prohibited, a measure that partially protects the shelf population where densities are lower, but which has no effect in protecting the main population on the shelf slope. Possible changes in fishing policy, such as allowing night fishing, would not result in enhanced catches of the main, slope population, but it would probably further deplete the shelf population that may currently serve as an important reservoir for the overall population of Nephrops in the region. 
It is clear that studies of behavioural rhythmicity have important inputs to make in framing fishing policy for Norway lobsters over their geographical range in N.W. Europe and the Mediterranean. Moreover, an understanding of daily and tidal movements is also necessary in framing fish management strategies for North Sea plaice, Pleuronectes platessa. When migrating between spawning and feeding grounds this flatfish swims up into the water column when the tide flows in the migratory direction, but remains on the seabed when the tidal stream reverses (Metcalfe et al., 1990; Arnold and Metcalfe, 1996; Morgan, 2001). Such studies, together with others concerned with vertically migrating epibenthic species (Al-Adhub and Naylor, 1977), emphasize the implications of chronobiology in understanding and managing benthic trawl fisheries.

\section{CHRONOBIOLOGY AND AQUACULTURE}

The study of chronobiology began with interest in specialized phenomena, but has grown to demonstrate that biological processes of daily and/or tidal rhythmicity are fundamental to the physiological makeup of eukaryotic organisms. Pittendrigh (1961) proposed that terrestrial organisms may be considered to comprise suites of endogenous circadian oscillators, and that optimum performance of an organism's physiology depended upon the correct environmental synchronization of its various internal oscillatory processes. The hypothesis was tested and confirmed in insects (Aschoff et al., 1971; Pittendrigh and Minnis, 1972; Saunders, 1972). Insect species cultured in non-24 h environmental cycles exhibited detrimental effects on growth and development, assumed to derive from internal desynchronization of their biological clocks. Tests of the hypothesis using marine crustaceans cultured in the laboratory were carried out by Dalley $(1979,1980$ a) who compared development and survival of the prawn Palaemon elegans in $24 \mathrm{~h}$ and non- $24 \mathrm{~h}$ cycles of light and dark. In those experiments prawns were reared from the egg, to zoea, post-larva and juvenile stages in three types of light/dark cycle: $12 \mathrm{~h}: 12 \mathrm{~h} \mathrm{~L}: \mathrm{D}, 8 \mathrm{~h}: 8 \mathrm{~h} \mathrm{~L}: \mathrm{D}$ and random L:D. In all cases the prawns received the same amount of light in each $48 \mathrm{~h}$ period, were maintained at the same constant temperature and fed at irregular intervals throughout. Results indicated that growth was retarded and survival to the juvenile stage was significantly reduced in the $8 \mathrm{~h}: 8 \mathrm{~h}$ and random L:D

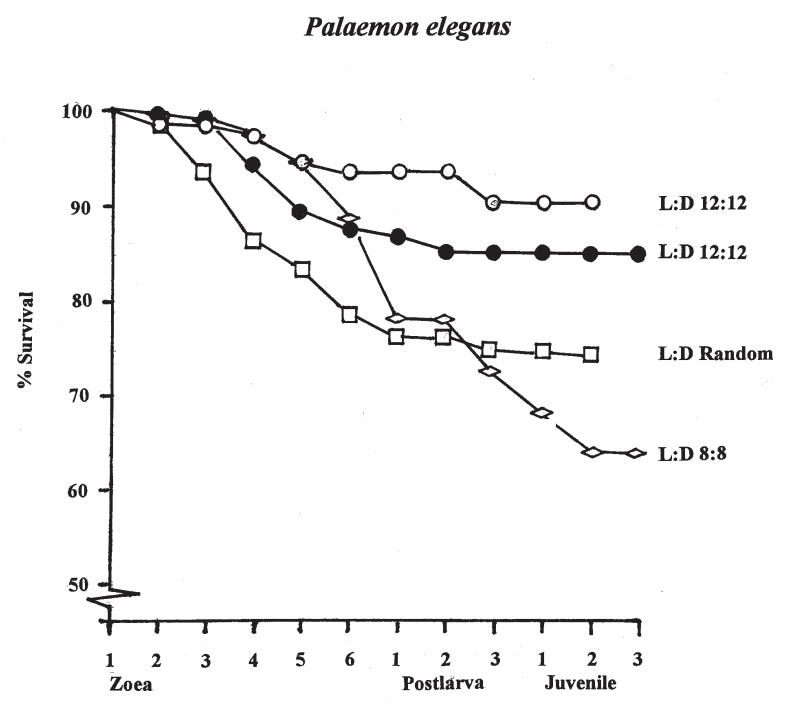

FIG. 3. - The percentage of larvae of the prawn Palaemon elegans surviving through six zoea stages and three post-larval stages to early juveniles during exposure to circadian (L:D $12 \mathrm{~h}: 12 \mathrm{~h}$ ) and non-circadian ( L:D 8 h:8 h; L:D random) light regimes. Forty to fifty larvae were used at the start of each experiment. Open and closed circle plots are repeat experiments under L:D $12 \mathrm{~h}: 12 \mathrm{~h}$ conditions (After Dalley, 1979).

conditions compared with the $12 \mathrm{~h}: 12 \mathrm{~h}$ controls (Fig. 3). In a similar study using the brown shrimp Crangon crangon survival, though not growth and morphological development, was adversely in noncircadian cycles (Dalley, 1980b). In Palaemon the sex ratio was also shown to vary according to light/dark regimes in which the prawns were cultured. In $12 \mathrm{~h}: 12 \mathrm{~h} \mathrm{~L}$ :D the ratio was around the normal of 1:1 males:females, but prawns cultured in $8 \mathrm{~h}: 8 \mathrm{~h} \mathrm{~L}: \mathrm{D}$ and random light/dark cycles were predominantly male (Dalley, 1979). It was previously known that the amount of light received by a crustacean during development influenced the sex ratio, as Bulnheim $(1978,1991)$ showed and studied further in the marine amphipod Gammarus duebeni. Daily light/dark cycles in which light predominates induces maleness, whilst femaleness is most common in dark-dominated cycles. However, the experiments with Palaemon, with equal exposure to light and dark, clearly indicate that non-24 h cycles also reduce survivorship, particularly of females. As in insects, this reduced survivorship is assumed to be related to the mismatch between imposed environmental cycles and the prawns' endogenous biological clockwork. Given this interpretation of the relationship between environmental and endogenous rhythmicity, with its potential impact on survival and growth, and the widespread occurrence of endogenous biological rhythms in animals and plants (Nay- 
lor, 1985; Palmer 1995a), the implications are clear for the artificial culture of crustaceans, molluscs and fish for commercial purposes.

In aquaculture studies, particularly of fish, research effort has concentrated extensively on assessing the effects on growth of various light and dark intervals within the standard $24 \mathrm{~h}$ photoperiod (Stefansson et al., 1989, 1991). This is generally thought to be a more important aspect of light controlling fish development than, say, light intensity or spectral composition. With freshwater trout, experimental modification of the seasonally-varying cycle of day length has been used for the production of year-round supplies of eggs for commercial fish farms (Dustan and Bromage, 1986). Also, similar photoperiod manipulation is the tool most used by farms to control growth, reproduction and smoltification of Atlantic salmon (Berrill et al., 2003), though the physiological mechanisms underlying such commercial manipulations are still poorly understood. Increasing awareness of the likely occurrence of endogenous rhythms in cultured fish has, however, prompted studies, for example, of flexibility in rhythms of feeding (Boujard et al., 1995). Those authors demonstrated clear evidence of circadian rhythms of feeding in rainbow trout; fish fed at midnight showed lower growth performance and nutrient retention than fish fed at dawn. Endogenous circadian rhythms of feeding in rainbow trout and European catfish were found to be less responsive to phase-setting in new light/dark cycles than those of sea bass and carp. Such findings have clear implications for the aquaculture industry with regard to the development of intermittent feeding regimes to avoid waste from overfeeding. An understanding the limits of entrainment of endogenous rhythms would also be important in attempts to enhance fish growth in "daily" light/dark cycles of less than $24 \mathrm{~h}$. On the evidence available from invertebrates (see above) exposure to "days" much shorter than $24 \mathrm{~h}$ may result in the disruption of circadian physiology of aquaculture species. However, it would be of interest to investigate the survival and growth of fish in light/dark cycles slightly shorter than $24 \mathrm{~h}$ periodicity, within the lower limit of circadian variability of the species concerned. A priori one could postulate that exposure to shorter "days" might speed up growth rates provided the underlying circadian physiology is not perturbed.

A further important application of chronobiology in aquaculture is the emergence of evidence of endogenous circa-annual rhythmicity in salmonid fish (Dustan and Bromage, 1991). Those authors kept rainbow trout for up to 51 months in a constant schedule of $6 \mathrm{~h}$ light and $18 \mathrm{~h}$ darkness (L:D 6:18), at constant temperature and constant feeding rate. The fish exhibited free-running circa-annual rhythms of gonadal maturation and ovulation which were self-sustaining for three circa-annual cycles. The role of photoperiodic manipulation, against the background of circa-annual and circadian periodicity, needs to be more fully evaluated as a basis for increased aquaculture yields (Berrill et al., 2003).

\section{ACKNOWLEDGEMENTS}

I am grateful to colleagues for advice concerning literature on fisheries and aquaculture, particularly Drs. P. Abelló and I. Berrill.

\section{REFERENCES}

Aguzzi, J., F. Sardà, P. Abelló, J.B. Company and G. Rotllant. 2003. Diel and seasonal patterns of Nephrops norvegicus (Decapoda:Nephropidae) catchability in the western Mediterranean. Mar. Ecol. Prog. Ser., 258: 201-211.

Aguzzi, J., J.B. Company and P. Abelló. - 2004. Locomotor activity rhythms of continental slope Nephrops norvegicus (Decapoda: Nephropidae). J. Crust. Biol., 24(2): 282-290.

Al-Adhub, A.H.Y. and E. Naylor. - 1977. Daily variations in Dichelopandalus bonnieri (Caullery) as a component of the epibenthos. In: B. Keegan, P. O'Ceidigh and P.J.S. Boaden (eds.), Biology of benthic organisms, pp. 1-6. Europ. Mar. Biol. Symp., 11. Pergamon Press, New York.

Aréchiga, H. and R.J.A. Atkinson. - 1975. The eye, and some effects of light on locomotor activity in Nephrops norvegicus. Mar. Biol., 32: 63-76.

Aréchiga, H. and L. Rodríguez-Sosa. - 1997. Coupling of environmental and endogenous factors in the control of rhythmic behaviour in decapod crustaceans. J. mar. biol. Ass. U.K.,77: 17-29.

Arnold, G.P. and J.P. Metcalfe. - 1996. Seasonal migrations of plaice (Pleuronectes platessa L.) through the Dover Strait. Mar. Biol., 127:151-160.

Aschoff, J., U. von Saint-Paul and R. Wever. - 1971. The longevity of flies under the influence of time displacement. Naturwiss., 58: 574 .

Atkinson, R.J.A. and E. Naylor. - 1976. An endogenous activity rhythm and rhythmicity of catches of Nephrops norvegicus (L). J. exp. mar. Biol. Ecol., 25: 95-108.

Bentley, M.G., P.J.W. Olive and K. Last. - 2001. Sexual satellites, moonlight and nuptial dances of worms: The influence of the moon on reproduction of marine animals. Earth Moon Planets, 85-86: 67-84.

Berrill, I.K., M.J.R. Porter, A. Smart, D. Mitchell and N.R. Bromage. - 2003. Photoperiodic effects on precocious maturation, growth and smoltification in Atlantic salmon, Salmo salar. Aquaculture, 222: 239-252.

Boujard, T., P. Divanach, A. Gelineau, M. Jourdan, M. Kentouri and M. Mambrini. - 1995. Flexibility in the circadian rhythm of feeding in fishes. Biol. Rhythm. Res., 26(4): 371-372.

Browman, H.I. and K.I. Stergiou. - 2004. Perpectives on ecosystem-based approaches to management of marine resources. Mar. Ecol. Prog. Ser., 274: 269-303.

Brown, F.A. - 1960. Responses to pervasive geophysical factors and the biological clock problem. Cold Spr. Harb. Symp. quant. Biol., 25: 57-71. 
Brown, F.A. - 1972. The "clocks" timing biological rhythms. Amer. Scient., 60: 756-766.

Bulnheim, H.P. - 1978. Interaction between genetic, external and parasitic factors in sex determination of the crustacean amphipod Gammarus duebeni. Helg. wiss. Meeres., 31: 1-33.

Bulnheim, H.P. - 1997. Zur oekophysiologie, sexualität und populationsgenetik litoraler Gammaridea- ein überblick. Helg. Meeresuntersuch., 45: 381-401.

Caspers, H. - 1984. Spawning periodicity and habitat of the Palolo worm Eunice viridis in the Samoan islands. Mar. Biol., 79: 229-236.

Chapman, C.J. and A.L. Rice. - 1971. Some direct observations on the ecology and behaviour of the Norway lobster Nephrops norvegicus. Mar. Biol., 10: 321-329.

Cushing, D.H. - 1969. The regularity of the spawning season in some fishes. J. cons. Int. Explor. Mer., 33: 81-92.

Cushing, D.H. - 1990. Plankton production and year-class strength in fish populations: an update of the match/mismatch hypothesis. Adv. Mar. Biol., 26: 249-293.

Cushing, D.H. - 1996. Towards a science of recruitment in fish populations. Excellence in Ecology, O. Kinne (ed.). Ecology Institute, Oldendorf/Luhe, Germany.

Daan, S. - 1982. Circadian rhythms in animals and plants. In: J. Brady (ed.), Biological Timekeeping. Soc. Exp. Biol. Sem. Ser., 14:11-32.

Dalley, R. - 1979. Effects of non-circadian light cycles on the survival and development of Palaemon elegans reared in the laboratory. In: E. Naylor and R.G. Hartnoll (eds.), Cyclical phenomena in marine plants and animals, pp. 157-163. Europ. Mar. Biol. Symp. 13. Pergamon Press, Oxford.

Dalley, R. - 1980a. Effects of non-circadian light/dark cycles on the growth and moulting of Palaemon elegans reared in the laboratory. Mar. Biol., 56: 71-78.

Dalley, R. - 1980b. The survival and development of the shrimp Crangon crangon (L), reared in the laboratory under non-circadian light/dark cycles. J. exp. mar. Biol. Ecol., 47: 101-112.

Dustan, J. and N. Bromage. - 1986. Photoperiodic mechanisms and rhythms of reproduction in the female rainbow trout. Fish Physiol. Bioch., 2: 35-51.

Dustan, J. and N. Bromage. - 1991. Circa-annual rhythms of gonadal maturation in female rainbow trout (Onchorhynchus mykiss). J. Biol. Rhythms, 6(1): 49-53.

Forward Jr, R.B. and R.A. Tankersley. - 2001. Selective tidalstream transport of marine animals. Oceanog. Mar. Biol. Ann. Rev., 39: 305-353.

Gibson, R.N. - 2003. Go with the flow: tidal migrations in marine animals. In: M.B. Jones, A. Ingólfsson, E. Ólafsson, G.V. Helgason, K. Gunnarsson and J. Svavarsson (eds.), Migrations and dispersal of marine organisms. Europ. Mar. Biol. Symp. 37. Hydrobiologia, 503: 153-161.

Hastings, M.H. and E. Naylor. - 1980. Ontogeny of an endogenous rhythm in Eurydice pulchra. J. exp. mar.Biol. Ecol., 46: 137-143.

Hauenschild, C. - 1960. Lunar periodicity. Cold Spr. Harb. Symp. Quant. Biol., 25: 491-497.

Helfrich-Foster, C. - 1995. The period clock gene is expressed in central nervous neurons which also produce a neuropeptide that reveals projections of the circadian pacemaker cells within the brain of Drosophila melanogaster. Proc. Nat. Acad.. Sci. U.S.A., 92: 612-616.

Jager, Z. - 1999. Selective tidal stream transport of flounder larvae (Platichthys flesus L.) in the Dollard (Ems estuary). Estuar. Coast. Shelf Sci., 49: 347-362.

Kennedy, F., E. Naylor and E. Jaramillo. - 2000. Ontogenetic differences in the circadian locomotor activity rhythm of the talitrid amphipod crustacean Orchestoidea tuberculata. Mar. Biol., 137: 511-517.

Kleinhooute, A. - 1928. De door het licht geregelde autonome bewegingen der Canavalia bläderen. Ph.D. Thesis, Delft University, Holland.

Korringa, P. - 1957. Lunar periodicity. Mem. Geol. Soc. Amer., 67: 917-934.

Loew, E.R. - 1976. Light and photoreceptor degeneration in the Norway lobster Nephrops norvegicus (L.). Proc. Roy. Soc. B.,193: 31-44.

Longhurst, A.R. - 1976. Vertical migration. In: D.H. Cushing and J.J. Walsh (eds.), The ecology of the seas, pp. 116-137. Blackwell Scientific Publications, Oxford

Metcalfe, J.D., G.P. Arnold and P.W. Webb. - 1990. The energet- ics of migration by selective tidal stream transport: an analysis of plaice tracked in the southern North Sea. J. mar. biol. Ass. U.K. 70: 149-162.

Moller, T.H. and E. Naylor. - 1980. Environmental influence on locomotor activity in Nephrops norvegicus (Crustacea: Decapoda). J. mar. biol. Ass. U.K., 60: 103-113.

Morgan, E. - 2001. The moon and life on earth. Earth Moon Planets, 85-86: 279-290.

Naylor, E. - 1982. Tidal and lunar rhythms in animals and plants. In: J. Brady (ed.), Biological Timekeeping. Soc. Exp. Biol. Sem. Ser. 14: 33-48.

Naylor, E. - 1985. Tidally rhythmic behaviour of marine animals. Symp. Soc. Exp. Biol., 39: 63-93.

Naylor, E. - 1988. Rhythmic behaviour of decapod crustaceans. Symp. Zool. Soc. Lond., 59: 177-199.

Naylor, E. - 1996. Crab clockwork: the case for interactive circatida and circadian oscillators controlling rhythmic locomotor activity of Carcinus maenas. Chronobiol. Internat., 13(3):153-161.

Naylor, E. - 1997. Crab clocks re-wound. Chronobiol. Internat., 14(4): 427-430.

Naylor, E. - 2001. Marine animal behaviour in relation to lunar phase. Earth Moon Planets, 85-86: 291-302.

Naylor, E. - 2002. Coastal animals that anticipate time and tide. Ocean Challenge, 11(3): 21-26.

Naylor, E. and R.J.A. Atkinson. - 1976. Rhythmic behaviour of Nephrops and some other marine crustaceans. In: P. SpencerDavies (ed.), Perspectives in experimental biology, Vol. I Zoology, pp.135-143. Pergamon Press, Oxford.

Naylor, E. and F. Kennedy. - 2003. Ontogeny of behavioural adaptations in beach crustaceans: some temporal considerations for integrated coastal zone management and conservation. Est. Coast Shelf Sci., 58S: 169-175.

Olive, P.J.W. - 1984. Environmental control of reproduction in Polychaeta. Fortschr. Zool., 29: 17-38.

Nielson, J.D. and R.I. Parry. - 1990. Diel vertical migrations of marine fishes: an obligate or facultative process?. Adv. mar. Biol., 26: 115-168.

Oakley, S.G. - 1979. Diurnal and seasonal changes in the timing of peak catches of Nephrops norvegicus reflecting changes in behaviour. In: E. Naylor and R.G. Hartnoll (eds.), Cyclical phenomena in marine plants and animals, pp. 367-374. Europ. Mar. Biol. Symp.13. Pergamon Press, Oxford.

Palmer, J.D. - 1995a. The biological rhythms and clocks of intertidal animals. Oxford University Press, Oxford and New York.

Palmer, J.D. - 1995b. - Review of the dual-clock control of tidal rhythms and the hypothesis that the same clock governs both circatidal and circadian rhythms. Chronobiol. Internat., 12(5): 299-310.

Palmer, J.D. - 1997. Dueling hypotheses: circatidal versus circalunidian battle basics. Chronobiol. Internat., 14(4): 337-346.

Pitman, S.J. and C.A. McAlpine. - 2003. Movements of marine fish and decapod crustaceans: process, theory and application. $A d v$. Mar. Biol., 44: 205-294.

Pittendrigh, C.S. and D.H. Minis. - 1972. Circadian systems: longevity as a function of circadian resonance in Drosophila melanogaster. Proc. Nat. Acad. Sci. U.S.A., 69: 1537-1539.

Rimmer, D.W. and B.F. Phillips. - 1979. Diurnal migration and vertical distribution of phyllosoma larvae of the western rock lobster Panulirus cygnus. Mar. Biol., 54: 109-124.

Saunders, D.S. - 1972. Circadian control of larval growth rate in Sarcophaga argyrostoma. Proc. Nat. Acad. Sci. U.S.A., 69: 2738-2740.

Semon, R. - 1905. Ueber die Erblichkeit der Tagesperiode. Biol. Zentr., 25: 241-252.

Sheppard, C. (ed.). - 2000. Seas at the millennium: an environmental evaluation. Vol 3 Global issues and processes. Pergamon Press, Amsterdam and Oxford.

Skov, M.W., R.G. Hartnoll, R.K. Ruwa, J.P. Shunula, M.Vannini and S. Cannicci. - 2005. Marching to a different drum: crabs synchronize reproduction to a fourteen month lunar-tidal cycle. Ecology, 86(5): 1164-1171.

Stefansson, S.O., G. Naevdal and T. Hansen - 1989. The influence of three unchanging photoperiods on growth and parr-smolt transformation in Atlantic salmon, Salmo salar L . J. Fish Biol., 39: $237-247$

Stefansson, S.O., B.T. Bjornsson, T. Hansen, C. Haux, G.L. Taranger and R.L. Saunders. - 1991. Growth, parr-smolt transformation, and changes in growth hormone of Atlantic salmon 
(Salmo salar) reared under different photoperiods. Canad. J. Fish. Aquat. Sci., 48: 2100-2108.

Wood, L. and J.H. Hargis. - 1971. Transport of bivalve larvae in a tidal estuary. In: D.J. Crisp (ed.), Larval biology. Light in the marine environment, pp. 29-44. Europ. Mar. Biol. Symp. 4. Cambridge University Press, London.

Zeng, C. and E. Naylor. - 1996a. Endogenous tidal rhythms of ver- tical migration in field collected zoea-1 larvae of the shore crab Carcinus maenas: implications for ebb tide offshore dispersal. Mar. Ecol. Prog. Ser., 132: 71-82.

Zeng, C. and E. Naylor. - 1996b. Occurrence in coastal waters and endogenous tidal swimming rhythms of late megalopae of the shore crab Carcinus maenas: implications for onshore recruitment. Mar. Ecol. Prog. Ser., 136: 69-79. 
